\title{
Carcass and meet characteristics of very young Angus $x$ Nelore steers in the Agreste Potiguar region ${ }^{1}$
}

\author{
Características de carcaça e da carne de novilhos superprecoces Angus x Nelore no \\ Agreste Potiguar
}

\author{
Debora Andréa Evangelista Façanha² ${ }^{2}$ Jacinara Hody Gurgel Morais Leite ${ }^{3 *}$, Rita de Cássia Ramos Egypto \\ Queiroga ${ }^{4}$, Roberto Germano Costa ${ }^{5}$, Déborah dos Santos Garruti ${ }^{6}$ e Tâmara Lúcia dos Santos Silva ${ }^{7}$
}

\begin{abstract}
This work aimed to evaluate the quantitative and qualitative characteristics of the carcass and meat of very young steers, 1/2 Red Angus x Nelore (NEL) and 3/4 Red Angus x Nelore (RED). Fifty males were used, 25 from each genetic group, fed in feedlots from weaning (7 months) until reaching the age for slaughter (15 months). A difference was observed between the genetic groups for gains at weaning (158.57 kg NEL and $181.60 \mathrm{~kg}$ RED ) but the weight at slaughter showed no statistical differences (412.33 kg NEL and $426.53 \mathrm{~kg}$ RED). Cold and hot carcass yield was not affected by the genetic group, with NEL bovines showing a yield of $50.49 \%$ and $52.55 \%$ and the RED of $50.91 \%$ and $52.89 \%$ respectively. The percentage of muscle (55\% NEL and 53\% RED), fat (26\% NEL and 27\% RED), bone (18\% NEL and 18\% RED), and thickness of subcutaneous fat (4.1 mm NEL and $4.0 \mathrm{~mm}$ RED) were similar for both genetic groups. The $3 / 4$ Angus $x$ Nelore animals showed a higher loss when thawing $(9.05 \%)$. There was no difference in such sensory characteristics as overall impression, tenderness, juiciness and shear force in the evaluated genotypes. The genetic groups showed a similarity of characteristics for meat as well as carcass.
\end{abstract}

Key words: Composition of the carcass. Feedlot. Thickness of fat. Tenderness.

RESUMO - Objetivou-se avaliar as características quantitativas e qualitativas de carcaça e da carne de novilhos superprecoces 1/2 Red Angus x Nelore (NEL) e 3/4 Red Angus x Nelore (RED). Foram utilizados 50 machos, sendo 25 de cada grupo genético, alimentados em confinamento desde o desmame ( 7 meses) até atingirem idade para abate (15 meses). Foi verificado diferença entre os grupos genéticos para os ganhos na desmama (158,57 kg NEL e 181,60 kg RED) e o peso ao abate não apresentou diferenças estatísticas (412,33 kg NEL e 426,53 kg RED). O rendimento de carcaça fria e quente não foi influenciado pelo grupo genético, com os bovinos NEL apresentando rendimento de 50,49 e 52,55\% e os RED 50,91 e $52,89 \%$, respectivamente. As porcentagens de músculo (55\% NEL e 53\% RED), gordura (26\% NEL e 27\% RED), osso ( $18 \%$ NEL e $18 \%$ RED), e espessura de gordura subcutânea (4,1 mm NEL e 4,0 mm RED) foram similares em ambos os grupos genéticos. Animais $3 / 4$ Angus x $1 / 2$ Nelore apresentaram maior perda por descongelamento $(9,05 \%)$. Não houve diferença para as características sensoriais como impressão global, maciez, suculência e força de cisalhamento nos genótipos avaliados. Os grupos genéticos apresentaram similaridade das características tanto da carne quanto da carcaça.

Palavras-chave: Composição da carcaça. Confinamento. Espessura de gordura. Maciez.

\footnotetext{
*Autor para correspondência

${ }^{1}$ Recebido para publicação em 19/04/2013; aprovado em 26/02/2014

Parte da Dissertação da última autora, apresentado ao Programa de Pós-Graduação em Ciência Animal

${ }^{2}$ Departamento de Ciência Animal, Universidade Federal Rural do Semi-Árido, Mossoró-RN, Brasil, deboraufersa@ @otmail.com

${ }^{3}$ Programa de Pós-Graduação em Ciência Animal, Departamento de Ciência Animal, Universidade Federal Rural do Semi-Árido, Mossoró-RN, Brasil, narinhazootecnista@hotmail.com

${ }^{4}$ Departamento de Agropecuária, Universidade Federal da Paraíba, campos IV, Bananeira-PB, Brasil, betogermano@ hotmail.com

${ }^{5}$ Departamento de Nutrição, Universidade Federal da Paraíba, João Pessoa-PB, Brasil, rcqueiroga@uol.com.br

${ }^{6}$ Embrapa Agroindústria Tropical, Fortaleza-CE, Brasil, deborah@ cnpat.embrapa.br

${ }^{7}$ Instituto Federal de Educação, Ciência e Tecnologia do Maranhão, Campus São Raimunda das Mangabeiras, São Luís-MA, Brasil, tamara.zte@ hotmail.com
} 


\section{INTRODUCTION}

Brazil is very important on the international scene in the export of beef (ANUALPEC, 2010), producers however should be aware of the needs of the consumer market, and not limit themselves simply to supplying more meat, but also to take into consideration aspects related to quality. Efficiency in the production of beef cattle is directly related to a reduction in the age for slaughter, the genetic potential of the animal and the feed efficiency of the flock.

For many years, the beef that reached Brazilian consumers was derived from animals slaughtered between 3 and 5 years of age, representing a product of low quality (RUBIANO et al., 2009) with animals that needed a greater amount of feed per kilo of meat produced thus decreasing the profit of the producer. This demonstrated the need for change in this segment of the production chain and the setting up of production systems which provided for the slaughter of ever-younger animals. In systems producing extra-young beef, animals are kept in confinement until reaching a live weight of $450 \mathrm{~kg}$, which should occur by the age of 15 months. Adoption of these systems therefore may possibly lead to a better usage of an area as it eliminates having to rear the animals on the property, and enables a faster rotation of capital, besides facilitating obtaining meat with better organoleptic characteristics and uniform carcasses, within those standards of quality necessary to a discriminating market.

In order to achieve younger animals for slaughter, cross-breeding is a strong ally in systems of beef-cattle production, when seeking to increase hybrid vigour that can promote an increase in weight gain and in the muscularity of the carcasses, reflecting in greater biological efficiency and increased productivity of the herds (PEREIRA et al., 2009). Caution is necessary in the selection of the genetic material to be used, in order to ensure the complementarity of the desirable characteristics from each breed; taking into consideration that the heritability of beef is fairly variable, it is of paramount importance to assess the interactions between the different genetic groups (PRADO et al., 2008a; PRADO et al., 2009a; ROCHA JÚNIOR et al., 2010; ROTTA et al., 2009). In Brazil, crosses between Bos taurus and Bos indicus are widely adopted with the aim of improving the performance of zebu cattle, which are adapted to the climatic conditions of the country, besides improving fat deposition and the tenderness of the meat (LEPETIT, 2008; PRADO et al., 2008b).

The Agreste region of the Brazilian state of Rio Grande do Norte shows good potential for systems of production of very young steers, which have already been adopted on some properties having the resources that make possible the management necessary for this type of animal, especially when it comes to feeding. However, it is extremely important to monitor these systems using technical criteria able to gauge their effectiveness, particularly regarding animals used for zootechnical ends. Without a doubt, industrial cross-breeding is the most widely used in the production of beef cattle in Brazil, however some producers question whether the higher proportion of European races results in faster growth and better meat quality, mainly due to the increase in marbling. The aim of this study therefore was to evaluate the characteristics of both the meat and carcasses of extra-young steers from two crosses, reared in a tropical environment: Industrial - 1/2 Red Angus x 1/2 Nelore (NEL) and Absorbent - 3/4 Red Angus x 1/4 Nelore (RED).

\section{MATERIAL AND METHODS}

The experiment was carried out by an agricultural company in the town of Ceará-Mirim, in the Agreste region of the state of Rio Grande do Norte. Fifty steers from two genetic groups were evaluated, $251 / 2$ Red Angus X 1/2 Nelore (NEL) and $253 / 4$ x Red Angus 1/4 Nelore (RED). Whilst being reared, the calves were kept together with the cows, feeding naturally by rotational grazing on marandu grass (Brachiaria Brizantha), known locally as capim braquiarão, and mombasa grass (Panicum maximum), until seven months of age when they were weaned and taken directly to confinement in feedlots for fattening, where they remained until reaching the age for slaughter, established as 15 months. During the fattening phase, their diet was made up of elephant grass, Mombasa-grass silage, barley, cottonseed and protein-enriched salt. Two different compositions were used in regard to the proportion of ingredients at the beginning and end of confinement (Table 1). This practice was adopted due to changes in the availability of ingredients. However, the different diets were given to both groups. Throughout the period of confinement, the animals received a diet containing $12 \%$ crude protein, which was provided ad libitum in two daily portions with constant water in the troughs. The diet was formulated to meet the requirements of beef cattle in the growing and finishing phases and taking into consideration weight gains of from 1.3 to $1.6 \mathrm{~kg} \mathrm{day}^{-1}$, in accordance with the recommendations of the National Research Council (1996).

Slaughter was carried out at 15 months by a commercial cold-storage company. When reaching the age for slaughter, the animals were weighed and placed on a no-solids fast for 16 hours and then shipped to the slaughterhouse. Slaughtering procedures were in accordance with the regulations of the company, which is the holder of a federal inspection certificate. Immediately after evisceration, the carcasses were identified and 
Table 1 - Composition of the feedlot diet given to the animals, according to the management system used on the farm

\begin{tabular}{lccc}
\hline \multicolumn{1}{c}{ Period } & Genetic Group & Live Weight $(\mathrm{kg})$ & AGD $\left(\mathrm{kg} \mathrm{animal}^{-1}\right)$ \\
\hline \multirow{2}{*}{ 1 month of age } & 1/2 Red Angus x Nelore & $103.03 \mathrm{a} \pm 1.182$ & $1.07 \mathrm{~b}$ \\
& 3/4 Red Angus x Nelore & $103.02 \mathrm{a} \pm 1.672$ & $1.17 \mathrm{a}$ \\
Weaning (7 months) & 1/2 Red Angus x Nelore & $158.57 \mathrm{~b} \pm 3.739$ & $0.87 \mathrm{~b}$ \\
& 3/4 Red Angus x Nelore & $181.60 \mathrm{a} \pm 4.929$ & $0.89 \mathrm{a}$ \\
Slaughter (15 months) & 1/2 Red Angus x Nelore & $412.33 \mathrm{a} \pm 8.942$ & \\
\hline
\end{tabular}

weighed to obtain the hot carcass weight (HCW), followed by determination of carcass yield (HCY). After being divided into half-carcasses, they were taken to the cold room, where they remained for 24 hours at $4^{\circ} \mathrm{C}$. After the cooling period, the cold carcass weight $(\mathrm{CCW})$ and cold carcass yield (CCY) were obtained. Measurements of carcass length were taken from the right half-carcass and measured from the anterior edge of the pubic bone to the medial cranial edge of the first rib. On the same halfcarcass, a perpendicular cut was made in the longissimus dorsi muscle level with the 12th rib, and the subcutaneous fat thickness (SFT) measured with calipers. In order to calculate the loin-eye area (LEA), the exposed longissimus dorsi muscle was drawn onto tracing paper. Tissue composition, represented by estimates of the percentages of bone, muscle and fat on the carcasses, was calculated by physical separation of the relevant sections of the 9 th, 10 th and 11 th ribs on the right half-carcass, following the method recommended by Hankins and Howe (1946).

Portions of the longissimus dorsi muscle, removed from the sections following evaluation of tissue percentage, were packaged and frozen. After freezing, three sub-samples were extracted from each of the muscle samples for quality analysis of the meat, done in the sensory-analysis laboratory of Embrapa AgroindústriaTropical. Thecentesimalanalysesincluded moisture, proteins and lipids. Moisture was determined following the analytical procedures of Association Of Official Analytical Chemists International (2012). Total lipids were measured according to the method of Folch et al., (1957). Protein was determined following the analytical procedures of Association Of Official Analytical Chemists International (2012), according to the Kjeldahl method, by applying a correction factor of 6.38 for the conversion of total nitrogen into protein nitrogen. The results of the analyses, carried out in triplicate, were grouped into arithmetic mean averages for each animal within each treatment.

From the same portion of the longissimus dorsi two samples were then taken, each $2.5 \mathrm{~cm}$ thick. One of these samples was removed from cooling and at an internal temperature of $5{ }^{\circ} \mathrm{C}$ was then baked in a preheated electric oven at $170{ }^{\circ} \mathrm{C}$. To monitor the internal temperature, a thermocouple attached to a digital thermometer was placed at the geometric centre of each sample. The specimens were turned when they reached $42{ }^{\circ} \mathrm{C}$ and removed from the oven on reaching an inner temperature of $70{ }^{\circ} \mathrm{C}$. They were then kept at room temperature until they reaching 24 ${ }^{\circ} \mathrm{C}$. From each sample three sub-samples, consisting of bundles of muscle fibre, were removed, each with an area of $1 \mathrm{~cm}^{2}$ cut perpendicular to the fibres. Two readings were taken from each sub-sample using a WarnerBratzler apparatus to determine shear force. The remaining sample was cut into cubes of $2 \mathrm{~cm}^{3}$ which were distributed still hot to a panel of five properlytrained tasters. The overall impression of the samples was assessed on a structured, nine-point hedonic scale (PERYAM; PILGRIM, 1957), ranging from 1 (like extremely) to 9 (dislike extremely). The intensity of the attributes of tenderness and juiciness were included on the same evaluation form (MEILGAARD; CIVILLE; CARR, 1987) using a structured, seven-point linear scale on which the trained tasters gave scores for beef quality of from 1 (not at all juicy) to 7 (very juicy) and 1 (not at all tender) to 7 (very tender), respectively for the characteristics of juiciness and tenderness.

A completely randomised experimental design was used, with two treatments representing the genetic groups $1 / 2$ Red Angus x 1/2 Nelore (NEL) and 3/4 Red Angus x 1/4 Nelore (RED).

Variance analysis was carried out and the Pearson correlation (STATISTICAL ANALYSIS SYSTEM, 1998) calculated, according to the following model:

$Y_{i j}=\mu+G_{i}+e_{i j}$

where: $\mathrm{Y}=$ observation relating to animal $\mathrm{j}$ belonging to genetic group $\mathrm{i} ; \mu=$ general mean of all observations; $\mathrm{G}_{\mathrm{i}}=$ effect of genetic group $\mathrm{i}$; and $\mathrm{e}_{\mathrm{ij}}=$ random error associated with each observation. 


\section{RESULTS AND DISCUSSION}

The initial average weight for both genetic groups was similar, precisely due to the selection of the most uniform animals possible, in order to avoid the effect of initial weight influencing slaughter weight, as well as the other characteristics (Table 2).

During the experiment, greater weight gain was seen in animals with a higher proportion of Red Angus (RED), which may be explained by the faster rate of growth, a marked feature of European breeds. In the present study however, this superiority of the animals from the $3 / 4$ Red Angus $x 1 / 4$ Nelore (RED) group did not persist to the time of slaughter, which was carried out at 15 months when the live weights were similar.

Animals with a lower proportion of Angus ( $1 / 2 \mathrm{Red}$ Angus $\mathrm{x} 1 / 2$ Nelore, NEL) but showing the same performance in slaughter weight and hot and cold carcass yield when compared to the $3 / 4$ Red Angus x $1 / 4$ Nelore animals, gives an interesting result since it may reflect the productive efficiency of those animals having the highest proportion of Nelore, as these generally have low nutritional requirements and are more resistant to disease and heat stress, a fact of great importance for the region under study. In addition, animals from industrial cross-breeding ( $1 / 2$ Angus) are slaughtered one generation before those which come from absorbent crossbreeding ( $3 / 4$ Angus), thus increasing the turnover of animals in the production system, reflecting in a greater number of animals slaughtered for a particular period of time. Some authors have observed different results, in which pure Nelore cattle presented lower weights at slaughter in extra-young systems when compared to European breeds (PEREIRA et al., 2009; RUBIANO et al., 2009; SOUZA et al., 2009). This is possibly due to differences in the environmental conditions in which the experiments were conducted.

There was no difference in genetic group for carcass yield, which may have happened due to zebu cattle having a thinner bone-structure and thinner skin and therefore being lighter as well as having lower head weight (Table 3).

Table 2 - Live Weight of very young steers bred in the Agreste region of Rio Grande do Norte

\begin{tabular}{|c|c|c|c|c|}
\hline \multirow{2}{*}{ Variable } & \multicolumn{2}{|c|}{ Genetic Group } & \multirow{2}{*}{ Média } & \multirow{2}{*}{$\mathrm{CV}(\%)$} \\
\hline & NEL & RED & & \\
\hline Hot carcass weight, $\mathrm{kg}$ & $216.53^{\mathrm{ns}}$ & $225.03^{\mathrm{ns}}$ & 222.20 & 8.83 \\
\hline Cold carcass weight., $\mathrm{kg}$ & $204.07^{\mathrm{ns}}$ & $204.65^{\mathrm{ns}}$ & 204.43 & 7.75 \\
\hline Loss from cooling, $\%$ & $5.73 b$ & $9.05 \mathrm{a}$ & 7.39 & 20.00 \\
\hline Hot carcass yield, $\%$ & $52.55^{\mathrm{ns}}$ & $52.89^{\text {ns }}$ & 52.78 & 6.33 \\
\hline Cold carcass yield, $\%$ & $50.49^{\text {ns }}$ & $50.91^{\mathrm{ns}}$ & 50.75 & 8.42 \\
\hline Thickness subcutaneous fat, mm & $4.1^{\mathrm{ns}}$ & $4.0^{\mathrm{ns}}$ & 4.1 & 43.03 \\
\hline Loin eye area, $\mathrm{cm} 2$ & $8.9^{\mathrm{ns}}$ & $8.9^{\mathrm{ns}}$ & 8.9 & 35.66 \\
\hline Length of carcass, $\mathrm{cm}$ & $157.0^{\mathrm{ns}}$ & $169.0^{\mathrm{ns}}$ & 165.0 & 13.54 \\
\hline
\end{tabular}

AGD: Average daily weight gain; Averages followed by different letters in the same column differ $(\mathrm{p}<0.05)$ by Tukey test at $5 \%$ probability

Table 3 - Carcass characteristics of very young steers from different genetic groups reared in the Agreste region of Rio Grande do Norte

\begin{tabular}{|c|c|c|c|c|}
\hline \multirow{2}{*}{ Carcass Characteristics } & \multicolumn{4}{|c|}{ 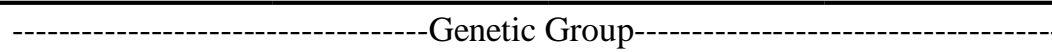 } \\
\hline & NEL & RED & Average & $\mathrm{CV}(\%)$ \\
\hline Muscle, $\%$ & $55.0^{\mathrm{ns}}$ & $53.0^{\mathrm{ns}}$ & 54.0 & 10.61 \\
\hline Fat, \% & $26.0^{\mathrm{ns}}$ & $27.0^{\mathrm{ns}}$ & 27.0 & 26.14 \\
\hline Bone, \% & $18.0^{\mathrm{ns}}$ & $18.0^{\mathrm{ns}}$ & 18.0 & 18.04 \\
\hline Edible portion, $* * \%$ & $81.0^{\mathrm{ns}}$ & $81.0^{\mathrm{ns}}$ & 81.0 & 4.09 \\
\hline Muscle to Bone Ratio & $3.05^{\mathrm{ns}}$ & $2.94^{\mathrm{ns}}$ & 2.99 & 5.35 \\
\hline Muscle to Bone to Fat Ratio & $4.5^{\mathrm{ns}}$ & $4.5^{\mathrm{ns}}$ & 4.5 & 7.08 \\
\hline
\end{tabular}

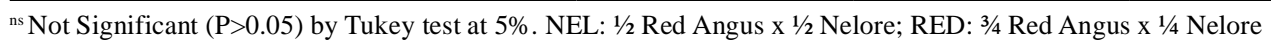


Subcutaneous fat is becoming an important indicator of quality, as it has a direct influence on the rate of cooling of the carcass, behaving as an efficient thermal insulator and preventing fluid loss and change in colour during cooling (PRADO et al., 2009b). The animals tested presented the minimum coverage thickness required by slaughterhouses, between 3 and $6 \mathrm{~mm}$, demonstrating the good finishing capacity of the carcasses of extra-young steers.

There was a difference in cooling losses of the carcasses from the genetic groups tested. Animals from the $3 / 4$ Red Angus x $1 / 4$ Nelore group had higher losses $(9.05 \%)$ than $1 / 2$ Red Angus x 1/2 Nelore (5.73\%). These losses may be caused by factors related to cooling of the carcasses in industry or to the occurrence of a higher level of pre-slaughter stress (JELENIKOVÁ et al., 2008; VAZ et al., 2010). When the animal is under stress, the muscles tend to use the glycogen reserves, reducing the formation of lactic acid and thus preventing the $\mathrm{pH}$ from decreasing normally. This may favour a lower loss of water from the carcass of those animals with a larger proportion of zebu (LAWRIE, 2005). Maggioni et al. (2012) also observed lower cooling losses in cattle with a higher proportion of Nelore genes and attributed the fact to the type of muscle fibre of these animals, which presented a higher frequency of slow-contraction (slow oxidative) fibres, these fibres displayed a negative correlation with water loss, because they hinder the drop in $\mathrm{pH}$.

The loin eye area (LEA) did not differ between the genotypes studied. Bos taurus animals tend to have a greater LEA in relation to zebu cattle, as they have faster growth rates. In this way, the results for this characteristic may demonstrate the positive effect of both crosses on the increase in muscularity.
Carcass length did not differ significantly between the genetic groups evaluated; in general Angus cattle tend to have a smaller size compared to Nelore.

The levels of muscle, fat and bones of the animal are important in determining the quality of the meat (LAWRIE, 2005). No difference was found between genotypes for any of the variables tested (Table 4). Souza et al. (2012) found differences in tissue-deposition rates between the genetic groups Nelore, $1 / 2$ Nelore $x$ Angus and $1 / 2$ Nelore $x$ Simmental, in which the Nelore $x$ Angus animals showed the highest percentage of fat $(26.09 \%)$, greater muscle weight $(59.63 \%)$ but no differences in bone percentage (14.28\%).

There was no difference between the groups for muscle to bone ratio (3.05 and 2.94) and muscle to fat to bone (4.5 and 4.5) for $1 / 2$ Red Angus x $1 / 2$ Nelore animals and 3/4 Red Angus x 1/4 Nelore animals respectively. Evaluating the muscle to bone ratio is important because this ratio represents the amount of desirable tissue on the carcass (muscle) compared to that which is not used for human consumption. It is interesting to consider that until the animal reaches maturity muscle tissue is the main constituent of weight gain and that after puberty there is more fat deposition on the carcass. The ratio between muscle and fat has also been presented as of great importance, especially nowadays in which there is great concern over the intake of fat (triglycerides) and its possible negative effects on human health, aggravated by a sedentary lifestyle and lack of exercise.

In general the loin eye area (LEA) correlated directly with the live slaughter weight, hot carcass weight and subcutaneous fat thickness (SFT) (Table 5), which was expected, because these characteristics show a strong correlation with the growth rate of the animals (BIANCHINI et al., 2007). The correlation between LEA

Table 4 - Tissue composition in the carcass of very young Angus x Nelore steers from different genetic groups, reared in the the Agreste region of Rio Grande do Norte

\begin{tabular}{|c|c|c|c|c|}
\hline \multirow{2}{*}{ Carcass Characteristics } & \multicolumn{4}{|c|}{----------------------------------Genetic Group------------------------------------. } \\
\hline & NEL & RED & Average & $\mathrm{CV}(\%)$ \\
\hline Muscle, $\%$ & $55.0^{\mathrm{ns}}$ & $53.0^{\mathrm{ns}}$ & 54.0 & 10.61 \\
\hline Fat, \% & $26.0^{\mathrm{ns}}$ & $27.0^{\mathrm{ns}}$ & 27.0 & 26.14 \\
\hline Bone, $\%$ & $18.0^{\mathrm{ns}}$ & $18.0^{\mathrm{ns}}$ & 18.0 & 18.04 \\
\hline Edible portion, $* * \%$ & $81.0^{\mathrm{ns}}$ & $81.0^{\mathrm{ns}}$ & 81.0 & 4.09 \\
\hline Muscle to Bone Ratio & $3.05^{\mathrm{ns}}$ & $2.94^{\mathrm{ns}}$ & 2.99 & 5.35 \\
\hline Muscle to Bone to Fat Ratio & $4.5^{\mathrm{ns}}$ & $4.5^{\mathrm{ns}}$ & 4.5 & 7.08 \\
\hline
\end{tabular}

**Edible portion is made up of the sum of muscle and fat. ${ }^{\text {ns }}$ Not Significant $(\mathrm{P}>0.05)$ by Tukey test at $5 \%$. NEL: $1 / 2$ Red Angus $x{ }^{1 / 2}$ Nelore; RED: $3 / 4$ Red Angus x $1 / 4$ Nelore 
and SFT reinforces the practice which is carried out in order to determine when to slaughter the animals, as these two variables are associated with weight gain and the ideal time for slaughter. Subcutaneous fat has become an indicator of quality since it influences the refrigeration rate of the carcass and acts as a thermal insulator preventing the loss of liquid during cooling.

The values found for shear strength (Table 6) indicate tender meat since, according to Bickerstaffe et al.(1997), following the results of the analysis for shear strength by the Warner-Bratzler method, they classified meat texture as soft (up to $8.6 \mathrm{kgf} \mathrm{cm}^{-2}$ ), acceptable ( 8 to $11 \mathrm{kgf} \mathrm{cm}^{-2}$ ) and hard (above $11 \mathrm{kgf} \mathrm{cm}^{-2}$ ). Borges et al. (2006) focus on the importance of evaluating shear force by a physical method using a Warner-Bratzler cell, since this demonstrates a strong correlation with sensory evaluation of the meat. Several authors explain that the genetic factor is a parameter that greatly influences this characteristic (BIANCHINI et al., 2007; PEREIRA et al., 2009). Maggion et al. (2012) noticed that pure Nelore animals had meat with a lower shear force than the crossbred $1 / 2$ Red Angus x 1/2 Nelore, in this study however there was no difference in shear force for the meat from the groups under study, both having meat which was tender.

One sensory characteristic of great importance in meat refers to its tenderness: in general there is a tendency for meat from young animals to be more tender, this being due to the accumulation and mainly to

Table 5 - Pearson correlation coefficient between the carcass characteristics of very young steers from different genetic groups

\begin{tabular}{|c|c|c|c|c|c|c|c|c|c|}
\hline Variable & $\mathrm{HCW}$ & $\mathrm{HCY}$ & $\mathrm{CCW}$ & $\mathrm{CCY}$ & SFT & LEA & $\mathrm{LC}$ & MUSC & FAT \\
\hline LWS & $0.79 * *$ & $-0.34 *$ & $0.41 *$ & $-0.49 *$ & $0.24^{\mathrm{ns}}$ & $0.70 * *$ & $-0.10^{\mathrm{ns}}$ & $0.45 *$ & $-0.42 *$ \\
\hline $\mathrm{HCW}$ & - & $0.29^{\text {ns }}$ & $0.93 * *$ & $0.39^{\mathrm{ns}}$ & $0.20^{\mathrm{ns}}$ & $0.64 * *$ & $-0.10^{\mathrm{ns}}$ & $0.33^{\mathrm{ns}}$ & $-0.26^{\mathrm{ns}}$ \\
\hline $\mathrm{HCY}$ & & - & $0.59 *$ & $0.94 * *$ & $-0.03^{\mathrm{ns}}$ & $-0.09^{\mathrm{ns}}$ & $-0.01^{\mathrm{ns}}$ & $-0.11^{\mathrm{ns}}$ & $0.15^{\mathrm{ns}}$ \\
\hline $\mathrm{CCW}$ & & & - & $0.58^{\mathrm{ns}}$ & $-0.29^{\mathrm{ns}}$ & $0.31^{\mathrm{ns}}$ & $-0.01^{\mathrm{ns}}$ & $0.21^{\mathrm{ns}}$ & $-0.12^{\mathrm{ns}}$ \\
\hline CCY & & & & - & $0.19^{\mathrm{ns}}$ & $0.28^{\mathrm{ns}}$ & $-0.27^{\mathrm{ns}}$ & $-0.21^{\mathrm{ns}}$ & $0.25^{\mathrm{ns}}$ \\
\hline SFT & & & & & - & $0.55 * *$ & $-0.53 *$ & $-0.36^{\mathrm{ns}}$ & $0.40^{\mathrm{ns}}$ \\
\hline LEA & & & & & & - & $-0.37 *$ & $0.15^{\text {ns }}$ & $-0.14^{\mathrm{ns}}$ \\
\hline $\mathrm{LC}$ & & & & & & & - & $0.27^{\mathrm{ns}}$ & $-0.31^{\mathrm{ns}}$ \\
\hline MUSC & & & & & & & & - & $-0.89 * *$ \\
\hline FAT & & & & & & & & & - \\
\hline
\end{tabular}

$* *(\mathrm{P}<0.01) ; *(\mathrm{P}<0.05)$; ${ }^{\text {ns }}$ Not Significant $(\mathrm{P}>0.05)$ by Tukey test. Live slaughter weight (LWS kg); hot carcass weight $(\mathrm{HCW} \mathrm{kg})$; hot carcass yield (HCY\%); cold carcass weight (CCW kg); cold carcass yield (CCY\%); subcutaneous fat thickness (SFT mm); loin eye area (LEA $\left.\mathrm{cm}^{2}\right)$; length of carcass $(\mathrm{LC} \mathrm{cm})$; percentage of muscle tissue (MÚSC\%); percentage of adipose tissue (GORD\%)

Table 6 - Meat quality of Angus x Nelore very young steers reared in the the Agreste region of Rio Grande do Norte

\begin{tabular}{lcccc}
\hline \multirow{2}{*}{ Characteristics } & \multicolumn{2}{c}{ Genetic Group } & General Average & CV $(\%)$ \\
\cline { 2 - 5 } & NEL & RED & 4.9 & 45.14 \\
\hline Overall impression, pointsa & $5.1^{\mathrm{ns}}$ & $4.7^{\mathrm{ns}}$ & 4.9 & 47.89 \\
Tenderness, pointsb & $4.9^{\mathrm{ns}}$ & $4.8^{\mathrm{ns}}$ & 3.8 & 57.86 \\
Juiciness, pointsc & $4.0^{\mathrm{ns}}$ & $3.7^{\mathrm{ns}}$ & 3.93 & 35.66 \\
Shear Force, kgf.cm- & $3.90^{\mathrm{ns}}$ & $3.96^{\mathrm{ns}}$ & 73.39 & 1.66 \\
Moisture, $\%$ & $73.0^{\mathrm{ns}}$ & $73.69^{\mathrm{ns}}$ & 26.5 & 6.53 \\
Protein, $\%$ & $26.5^{\mathrm{ns}}$ & $26.53^{\mathrm{ns}}$ & 2.42 & 40.26 \\
Lipids, $\%$ & $2.34^{\mathrm{ns}}$ & $2.55^{\mathrm{ns}}$ & \\
\hline
\end{tabular}

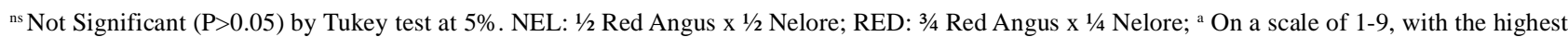
value corresponding to the rating "dislike extremely"; ${ }^{\mathrm{b}}$ On a scale of $1-7$, with the highest value corresponding to very tender meat; ${ }^{\mathrm{c}}$ On a scale of $1-7$, with the highest value corresponding to very juicy meat 
the maturation of connective tissue in the muscle fibres. The tenderness of the meat was analysed by tasters on a scale of from 1 (not at all tender) to 7 (very tender); the average for this characteristic was 4.9 points, indicating tender meat. For juiciness, the steaks were classified as "slightly above average" with an average of 3.93 points. The main cause of juiciness is the water and fat released at the start of chewing having a stimulating effect on salivation, animals of the RED group received a lower score for juiciness, which may be related to the higher loss of water (Table 3 ).

For an overall impression, the meat was evaluated from 9 (dislike extremely) to 1 (like extremely) receiving an average score of 4.9 points, indicating beef of good appearance, classified as "like". In general, the meat displayed good qualitative characteristics independent of the genetic group being analysed.

There was no difference in the genetic groups tested with respect to the deposition rate of the chemical constituents, protein and lipids. Differences in feeding may promote changes in the chemical components of the meat. The similarity of this feature may be due to the animals receiving the same diet and having the same age. Kuss et al. (2005) found differences in genetic groups tested, due to factors such as age at slaughter and weight, where the highest concentration of lipids was seen in meat from animals with a greater age at slaughter and greater weight.

\section{CONCLUSION}

Animals from Nelore $x$ Angus crossings may be used successfully in intensive systems, for the production of very young steers in the Agreste region of Rio Grande do Norte, since the products were able to meet market requirements such as weight, carcass yield and subcutaneous fat thickness. There was no difference between crossings for slaughter weight, carcass characteristics and meat quality. Industrial crossbreeding ( $1 / 2$ Angus $x 1 / 2$ Nelore), which enables the animals to be slaughtered one generation earlier, should therefore be recommended.

\section{REFERENCES}

ANUALPEC. Anuário da pecuária brasileira. Rio Grande do Sul: GAZETA. 2010. 28 p.

ASSOCIATION OF OFFICIAL ANALYTICAL CHEMISTS INTERNATIONAL. Official methods of analysis of the Association of Official Analytical Chemists. 19. ed. Gaithersburg: AOCA, 2012. v. 1.
BIANCHINI, W. et al. Efeito do grupo genético sobre as características de carcaça e maciez da carne fresca e maturada de bovinos superprecoces. Revista Brasileira de Zootecnia, v. 36, n. 6, p. 2109-2117, 2007.

BICKERSTAFFE, R., LE COUTEUR, C. E.; MORTON, J. D. Consistency of tenderness in New Zealand retail meat. In: International Congress of Meat Science Technology, v. 43, p. 196-197. 1997.

BORGES, A. S. et al. Medições instrumentais e sensoriais de dureza e suculência na carne caprina. Ciência e Tecnologia de Alimentos, v. 26, n. 4, p. 891-896, 2006.

FOLCH, J. et al. A simple method for the isolation and purification of total lipids from animal tissue. Journal of Biological Chemistry, v. 226, n. 1, p. 497-509, 1957.

HANKINS, O. G.; HOWE, P. E. Estimation of the composition of beef carcass and cuts. Whashignton, D. C.: United states Departament of Agriculture, 1946. 20 p. (Technical Bulletion, 926).

JELENIKOVÁ, J. et al. The influence of ante-mortem treatment on relationship between $\mathrm{pH}$ and tenterness of beef. Meat Science, v. 80, n. 3, p. 870-874, 2008.

KUSS, F. et al. Composição física da carcaça e qualidade da carne de vacas de descarte de diferentes grupos genéticos terminados em confinamentocom distintos pesos. Revista Brasileira de Zootecnia, v. 34, n. 4, p. 1285-1296, 2005.

LAWRIE, R. A Ciência da carne. 6. ed. Porto Alegre: Artmed, 2005.

LEPETIT, R. A. Collagen contribuition to meat toughness: theoretical aspects. Meat Science, v. 80, n. 4, p. 960-967, 2008.

MAGGIONI, D. et al. Grupos genéticos e graus de acabamento sobre qualidade da carne de bovinos. Ciências Agrárias, v. 33, n. 1, p. 391-402, 2012.

MEILGAARD, M. R.; CIVILLE, G. V.; CARR, B. T. Sensory evaluation techniques. Boca raton: CRC Press, 1987. 159 p. v. 2.

NATIONALRESEARCHCOUNCIL. Nutrient requirements of beef cattle. 7. ed. Washington, D.C.: National Academy Press, 1996. 242 p.

PEREIRA, P. M. R. C. et al. Características de carcaça e qualidade de carne de novilhos superprecoces de três grupos genéticos. Pesquisa Agropecuária Brasileira, v. 44, n. 11, p. 1520-1527, 2009.

$\begin{array}{llcr}\begin{array}{l}\text { PERYAM, D. R.; PILGRIM, F. J. } \\ \text { scale }\end{array} \text { method } & \begin{array}{r}\text { Hedonic } \\ \text { of }\end{array} \\ \text { preferences. Food Tecnhology, v. 11, n. 9, p. 9-14, } 1957 .\end{array}$

PRADO, I. N. et al. Carcass characteristics and chemical composition of the Longissimus muscle of Purunã and $1 / 2$ Purunã vs. $1 / 2$ Canchim bulls. Asian Australasian. Journal of Animal Science. v. 21, n. 9, p. 1296-1302, 2008a.

PRADO, I. N. et al. Carcass characteristics and chemical composition of the Longissimus muscle of crossbred bulls (Bos taurus indicus vs Bos taurus taurus) finished in feedlot. Journal of Animal Feed Science, v. 17, p. 295-306, 2008 b. 
PRADO, I. N. et al. Chemical and Fatty acid composition of Longissimus muscle of crossbred bulls finished in feedlot. Asian Australasian Journal of Animal Science, Seoul, v. 22, n. 7, p. 1054-1059, 2009a.

PRADO, J. M. et al. The effect of breed on chemical composition and fatty acid composition on Longissimus dorsi muscle of Brazilian beef cattle. Journal of Animal Feed and Science, v. 18, p. 231-240, 2009b.

ROCHA JÚNIOR, V. R. et al. Desempenho e características de carcaça de bovinos Nelore e mestiços terminados em confinamento. Revista Brasileira de Saúde e Produção Animal, v. 11, n. 3, p. 865-875, 2010.

ROTTA, P. P. et al. The effects of genetic groups, nutrition, finishing ystems and gender of Brazilian cattle on carcass characteristics and beef composition and appearance: a review. Asian-Australasian Journal Animal Science, v. 22, n. 12, p. 1718-1734, 2009.
RUBIANO, G. A. G. et al. Desempenho, características de carcaça e qualidade da carne de bovinos superprecoces das raças Canchim, Nelore e seus mestiços. Revista Brasileira de Zootecnia, v. 38, n. 12, p. 2490-2498. 2009.

STATISTICAL ANALYSIS SYSTEM. User's guide: statistics, version 6, 12. 4. ed. Cary, 1998. $842 \mathrm{p}$.

SOUZA, A. R. D. L. et al. Dieta com alto teor de gordura e desempenho de tourinhos de grupos genéticos diferentes em confinamento. Pesquisa Agropecuária Brasileira, v. 44, n. 7, p. 746-753, 2009.

SOUZA, E. J. O. et al. Taxa de deposição de tecidos corporais de novilhos Nelore e suas cruzas com Angus e Simental. Revista Brasileira de Saúde e Produção Animal, v. 13, n. 2, p. 344-459, 2012.

VAZ, F. N. et al. Características de carcaça e da carne de novilhos e novilhos superjovens, terminados com suplementação em pastagem cultivada. Ciência Animal Brasileira, v. 11, n. 1, p. 42-52, 2010. 